\title{
CAL SERIES ON LANGUAGE EDUCATION
}

Series Editors: Terrence G. Wiley, M. Beatriz Arias and

Joy Kreeft Peyton, Center for Applied Linguistics, Washington, DC, USA.

Current and aspiring education professionals need accessible, highquality, research-based resources on language learning, instruction, and assessment. This series provides such resources, serving to inform teachers' classroom practice, enhance teacher education, and build the background knowledge of undergraduate and graduate students in applied linguistics and other language-related fields.

The books in this series explore a broad range of issues in applied linguistics and language education and are written in a style that is accessible to a broad audience, including those who are new to the field. Each book addresses a topic of relevance to those who are studying or working in the fields of language learning, language instruction, and language assessment, whether in English as a second language or other world languages. Topic areas include approaches to language instruction and assessment; approaches to content instruction and assessment for language learners; professional development for educators working with language learners; principles of second language acquisition for educators; and connections between language policy and educational practice.

All books in this series are externally peer-reviewed.

Full details of all the books in this series and of all our other publications can be found on http://www.multilingual-matters.com, or by writing to Multilingual Matters, St Nicholas House, 31-34 High Street, Bristol BS1 2AW, UK. 


\section{Language, Learning, and Disability in the Education of Young Bilingual Children}

Edited by

Dina C. Castro and Alfredo J. Artiles 
DOI https://doi.org/10.21832/CASTRO1845

Names: Castro, Dina Carmela, editor.| Artiles, Alfredo J., editor.

Title: Language, Learning, and Disability in the Education of Young Bilingual Children/Edited by Dina C. Castro and Alfredo J. Artiles.

Description: Bristol, UK; Blue Ridge Summit, PA: Multilingual Matters, 2021. | Series: CAL Series on Language Education: 4 | Includes bibliographical references and index. | Summary: "Using an interdisciplinary perspective to discuss the intersection of language development and learning processes, this book summarizes current knowledge and represents the most critical issues regarding early childhood research, policy, and practice related to young bilingual children with disabilities" - Provided by publisher.

Identifiers: LCCN 2020052578 (print) | LCCN 2020052579 (ebook) | ISBN 9781800411838 (paperback) | ISBN 9781800411845 (hardback) | ISBN 9781800411852 (pdf) | ISBN 9781800411869 (epub) | ISBN 9781800411876 (kindle edition)

Subjects: LCSH: Children with disabilities - Education (Early childhood) | Children with disabilities - Language. | Bilingualism in children. |

Education, Bilingual.

Classification: LCC LC4019.3 .L36 2021 (print) | LCC LC4019.3 (ebook) | DDC $371.9-$ de 23

LC record available at https://lccn.loc.gov/2020052578

LC ebook record available at https://lccn.loc.gov/2020052579

Library of Congress Cataloging in Publication Data

A catalog record for this book is available from the Library of Congress.

British Library Cataloguing in Publication Data

A catalogue entry for this book is available from the British Library.

ISBN-13: 978-1-80041-184-5 (hbk)

ISBN-13: 978-1-80041-183-8 (pbk)

\section{Multilingual Matters}

UK: St Nicholas House, 31-34 High Street, Bristol BS1 2AW, UK.

USA: NBN, Blue Ridge Summit, PA, USA.

Website: www.multilingual-matters.com

Twitter: Multi_Ling_Mat

Facebook: https://www.facebook.com/multilingualmatters

Blog: www.channelviewpublications.wordpress.com

Copyright (C) 2021 Dina C. Castro, Alfredo J. Artiles and the authors of individual chapters.

All rights reserved. No part of this work may be reproduced in any form or by any means without permission in writing from the publisher.

The policy of Multilingual Matters/Channel View Publications is to use papers that are natural, renewable and recyclable products, made from wood grown in sustainable forests. In the manufacturing process of our books, and to further support our policy, preference is given to printers that have FSC and PEFC Chain of Custody certification. The FSC and/or PEFC logos will appear on those books where full certification has been granted to the printer concerned.

Typeset by Riverside Publishing Solutions. Printed and bound in the UK by the CPI Books Group Ltd.

Printed and bound in the US by NBN. 